\title{
Investigation the fatty acid profile of commercial black cumin seed oils and seed oil capsules: Application to real samples
}

\author{
Selin Isik ${ }^{1}$ Sinem Aslan Erdem ${ }^{* 2}$ and Murat Kartal ${ }^{3,4}$ \\ ${ }^{1}$ Department of Analytical Chemistry, Faculty of Pharmacy, Near East University, 99138 Nicosia, \\ Turkish Republic of Northern Cyprus \\ ${ }^{2}$ Department of Pharmacognosy, Faculty of Pharmacy, Ankara University, 06560, Ankara, Türkiye \\ ${ }^{3}$ Center of Education, Practice and Research in Phytotherapy, Bezmialem Vakif University,34093, \\ Fatih, Istanbul, Türkiye \\ ${ }^{4}$ Faculty of Pharmacy, Bezmialem Vakif University,34093, Fatih, Istanbul, Türkiye
}

(Received August, 25, 2019; Revised September 16,, 2019; Accepted September 18, 2019)

\begin{abstract}
Medicinal and aromatic plants are widely used around the world. Today, Black cumin (Nigella sativa L.), one of the most popular medicinal plants, offers numerous benefits for human health. Black cumin oil has known to be used for the treatment of asthma, hypertension, cancer, rheumatism, and headaches over the course of many years. In this study, ten different black cumin seed oils and seed oil capsules, which have been obtained from local markets in Turkey, were investigated for their fatty acid profiles as percentages via gas chromatography and mass spectroscopy (GC-MS). According to the results obtained, the major fatty acids found in capsules and oil samples were similar with small differences in terms of amount; linoleic, oleic and palmitic acids were found as major compounds; $35.27-58.15 \%, 25.06-51.83 \%, 7.29-12.88 \%$ in oil samples; $36.67-56.61 \%, 24.93-46.71 \%$, and $7.90-12.71 \%$ in seed oils capsule samples, respectively. This is the first study determining the fatty acid percentages of commercial black cumin seed oil and seed oil capsules.
\end{abstract}

Keywords: Nigella sativa L.; black cumin; fatty acid profile; seed oil; seed oil capsule; GC/MS. () 2019 ACG Publications. All rights reserved.

\section{Introduction}

Black cumin (Nigella sativa L.), is an annual plant belonging to the Ranunculaceae family. It is cultivated in different regions of world and has been widely used since the ancient Egypt era. Some Nigella seeds were also found in the tomb of Tutankhamen [1]. Black cumin is commonly known as "Çörek otu" in Turkish and has different usage forms, such as spice in salads, breads and pastry.

Black cumin oil is obtained from the seeds of the plant; it is considered as a valuable and edible oil due to its fatty acid content, tocochromanols, phytosterols, thymoquinone and its derivatives. The oil has antioxidant, antitumor, antiinflammatory, antibacterial, antidiabetic, antiulcer, gastroprotective properties [2-5]. Recently, the popularity of black cumin oil has been increasing as nutritional supplement due to its various benefits and known usage traditionally mentioned above. Among edible oils, black cumin oil is known to be 10 to 15 times expensive than palm oil, sunflower oil, etc. Its high price lead producers to adulteration with cheaper oils such as refined corn oil, sunflower oil as well as other cheaper and low-quality seed oils. It is important to detect if there is any adulteration. This is necessary for both consumers' safety and health. Thus, several methods have been developed for detecting adulteration of fixed oils: chromatographic methods (Gas Chromatography), Mass Spectroscopy, total synchronous fluorescence spectroscopy, Chemometric Analysis, Fourier Transform Infrared (FTIR) Spectroscopy, Raman techniques [6-9].

\footnotetext{
* Corresponding author E-Mail: sinemaslanerdem@yahoo.com
} 
Reported pharmacological properties of black cumin seed oils are: anti-cancer [10,11], antiinflammatory [12-15], cytotoxic [16-19], anti-asthmatic [20,21] , anti-microbial [22-26], antioxidant [27-32] as well as neuroprotective [33-39] and gastroprotective effects [40-47] .

Normally, before extraction, black cumin seeds have a lower Free Fatty Acid (FFA) content, which means there are long chained fatty acids [48]. Depending on the obtaining methods of oil such as extraction or pressing methods, the thymoquinone content and the fatty acid composition may negatively be altered because of high temperature and increased FFA content. Contrary to expectations, oils obtained by cold press machines (Figure 1.) may can also be affected due to being exposed to the high temperatures of the machine components.
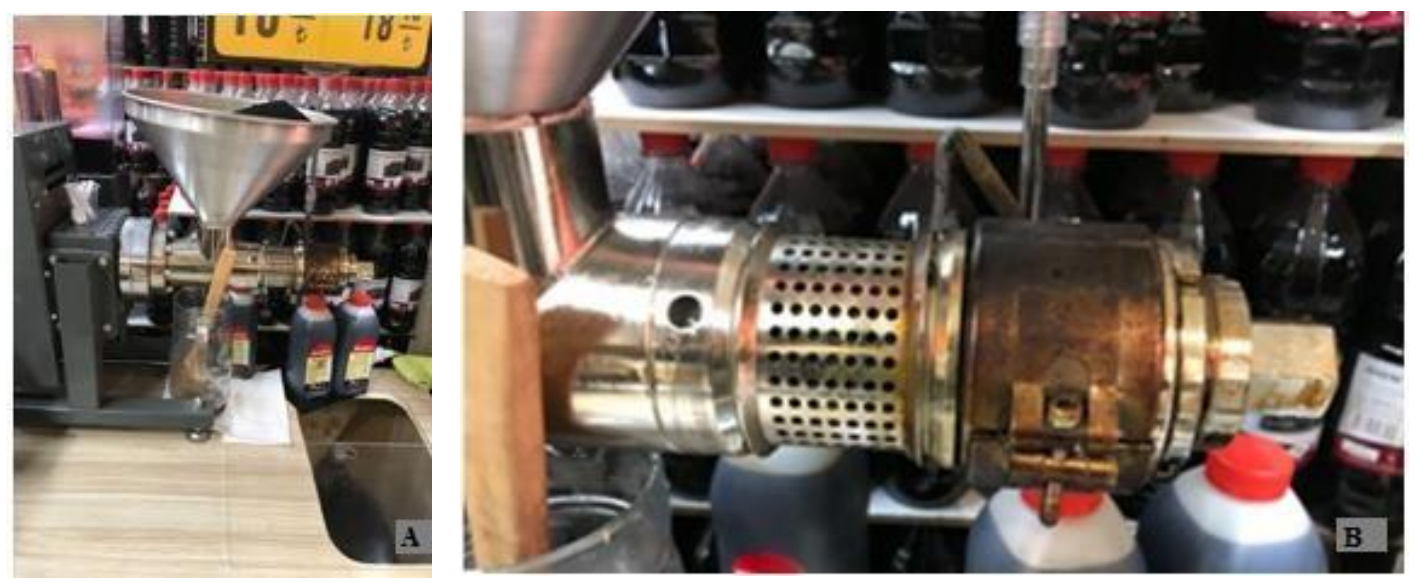

Figure 1. (A) Illustration of cold press machine for the extraction of black cumin seed oil.

(B) Heated components of a cold press machine. (Photo credit: Prof. Dr. Maksut Coşkun; used with his permission)

The aim of this study is to identify the fatty acid composition of black cumin seed oils and seed oil capsules as well as to investigate and reveal the differences between these products and also to find out if there is an adulteration or not. To the best of our knowledge, this is the first study determining the fatty acid percentage range scale of commercial black cumin oils and seed oil capsules.

\section{Materials and Methods}

\subsection{Sample Materials}

Black cumin oils and oil capsules were obtained from different local markets in Ankara, Turkey. Each sample used was from a different brand. Both oils and capsules were selected from cold- press extracted and conventional extracted. The black cumin oils and oil capsules were coded as NO and NOC, respectively.

\subsection{Preparation of Fatty Acid Methyl Esters from Samples}

For fatty acid methyl esterification (FAME), $150 \mathrm{mg}$ of the oils were placed in $25 \mathrm{~mL}$ volumetric flasks saponified by adding $4 \mathrm{~mL} 0.5 \mathrm{~N} \mathrm{NaOH} / \mathrm{MeOH}$ and then heated on a boiling water bath until the fatty bubbles disappeared. Next, $4 \mathrm{~mL}$ of $\mathrm{BF}_{3} / \mathrm{MeOH}$ was added to each flask and they were boiled on a Bunsen burner for 2.5 minutes. When the solutions had cooled down to room temperature, they were filled up to $25 \mathrm{~mL}$ with saturated sodium chloride solution. The oily part then, separated by adding hexane.

\subsection{Determination of FAMEs with Gas Chromatography and Mass Spectroscopy}

The obtained FAMEs were dissolved in $2 \mathrm{~mL} n$-hexane and $1 \mu \mathrm{L}$ of the samples was injected and analysed by Gas Chromatography-Mass Spectroscopy (GC/MS). Chromatographic analysis was 
performed using an Agilent 6890N-Network Gas Chromatography system which is combined with an Agilent 5973-Network Mass Detector (GC-MS). HP Innowax Capillary $(60.0 \mathrm{~m} \times 0.25 \mathrm{~mm} \times 0.25 \mu \mathrm{m})$ was used as a capillary column. The carrier gas was helium with $3.3 \mathrm{~mL} / \mathrm{min}$ flowrate and the injection volume was $1 \mu \mathrm{l}$. Column temperature was at $100{ }^{\circ} \mathrm{C}$ initially for $1 \mathrm{~min}$ after injection, gradually increased to $170{ }^{\circ} \mathrm{C}$ with $10^{\circ} \mathrm{C} / \mathrm{min}$ and increased to $215^{\circ} \mathrm{C}$ with $5{ }^{\circ} \mathrm{C} / \mathrm{min}$ for $5 \mathrm{~min}$. Then, the finally column temperature was increased to $240{ }^{\circ} \mathrm{C}$ with $10{ }^{\circ} \mathrm{C} / \mathrm{min}$ for $10.5 \mathrm{~min}$. Split mode (20:1) was used for the injection at $270{ }^{\circ} \mathrm{C}$. Temperatures of detector and injector were $280^{\circ} \mathrm{C}$ and 250

${ }^{\circ} \mathrm{C}$, respectively. The run time was $35 \mathrm{~min}$ [49].

\section{Results and Discussion}

For this study, fatty acid methyl esters (FAMEs) of commercially available black seed oils and black seed oil capsules of various brands on the market were formed and GC-MS and fatty acid profiles were obtained, which are summarized in Table 1 and Table 2, respectively. Black cumin oil samples are classified as NO and black cumin oil capsules are encoded as NOC.

The results as the percentages of the fatty acid content reveal that the major fatty acids found in capsules and oil samples were similar with small differences in terms of amount; linoleic acid (LA), oleic acid (OA) and palmitic acid (PA) were found as major compounds; $35.27-58.15 \%, 25.06-51.83 \%$, $7.29-12.88$ in oil samples ; 36.67-56.61\%, $24.93-46.71 \%$, and $7.90-12.71 \%$ in oil capsule samples, respectively.

Kaskoos [50] reported that the major fatty acids of black seed oil were LA (42.76\%), OA $(16.59 \%)$ and PA $(8.51 \%)$.

Lutterodt et al [51] studied the fatty acid profile of extracted seed oil and the major fatty acids found were LA (58.8-61.2\%), OA (22.6-24.5\%) and PA (13-13.3\%) .

Babayan et al,[52] reported that the major fatty acids of black seed oil were LA (56\%), OA $(24.6 \%)$ and PA (12\%).

In their study, Ramadan and Morsel [53] found the major fatty acids of black cumin seed oil to be LA (57.3\%), OA (24.1\%) and PA (13\%).

Tulukcu [54] collected black cumin seed oils from 8 different regions and studied their fatty acid profiles. As a result of his study, the major fatty acids of seeds were found to be La (54-70\%), OA $(15-24 \%)$ and PA (8.2-13.3).

Also a result of the study conducted by Atta [55], the major fatty acids of black seed oils were determined to be LA (47.5-49\%), OA (18.9-20.1\%) and PA (9.9-12.1\%).

According to Turkish Pharmacopoeia [56], black cumin oil should contain 40-60\% linoleic acid, $20-30 \%$ oleic acid and 10-20\% palmitic acid. When we compare the results with Turkish Pharmacopoeia, it is clearly that NO2 and NOC2 has lower linoleic acid percentages $(35.27 \%$ and $36.67 \%$, respectively); $\mathrm{NO} 2, \mathrm{NO} 3, \mathrm{NO} 4, \mathrm{NOC} 2$, NOC4 and NOC8 has lower palmitic acid percentages $(8.06,7.29,8.18,8.89,7.90,8.34 \%$, respectively) when compared to the pharmacopoeia values but the values are very close to the limitations. Oleic acid percentages of all samples are consistent with the ranges of Turkish Pharmacopoeia.

Among the oils studied, the major fatty acids of black seed oils and seed oil capsules were determined as linoleic acid (36-56\%), oleic acid (25-46\%) and palmitic acid (7-13\%). These results are consistent with the results of previous studies. High content of oleic acid supports its usage .

The term of "specialty oils" has usually been used for some oils which has special dietary or functional properties with the help of specific fatty acid they contain. Especially oleic and linoleic acids are two main members of these specific fatty acids. They have beneficial and prevention effects on cancer, cardiovascular, autoimmune and inflammatory diseases [57-59]. According to these findings it may be concluded that 18 of 20 samples, could help on prevention of cardiovascular, autoimmune and inflammatory diseases.

The results of our study on the fatty acid profile of black cumin seed oil and the results reported in previous literature research have been combined and approximately indicated in Table 3. 
Table 1. Fatty acid percentages of black cumin oils

\begin{tabular}{|c|c|c|c|c|c|c|c|c|c|c|}
\hline Fatty Acid & NO1 & NO 2 & NO 3 & NO4 & NO 5 & NO6 & NO 7 & NO 8 & NO9 & NO10 \\
\hline (C14:0) & - & - & & - & $0.15 \pm 0.01$ & - & - & $0.14 \pm 0.02$ & $0.16 \pm 0.02$ & - \\
\hline (C16:0) & $10.55 \pm 0.03$ & $8.06 \pm 0.24$ & $7.29 \pm 0.12$ & $8.18 \pm 0,19$ & $12.41 \pm 0.04$ & - & $12.88 \pm 0.1$ & $12.12 \pm 0.17$ & $12.62 \pm 0.25$ & - \\
\hline (C16:1) & - & - & & - & $0.16 \pm 0.02$ & - & - & $0.17 \pm 0.01$ & $0.17 \pm 0.02$ & - \\
\hline (C18:0) & $3.02 \pm 0.07$ & $0.89 \pm 0.01$ & $3.27 \pm 0.08$ & $3.64 \pm 0.17$ & $3.07 \pm 0.09$ & - & $2.97 \pm 0.08$ & $3.40 \pm 0.23$ & $3.34 \pm 0.09$ & - \\
\hline (C18:1) & $33.08 \pm 1.63$ & $51.83 \pm 0.20$ & $41.06 \pm 0.12$ & $28.94 \pm 0.31$ & $25.31 \pm 0.34$ & - & $25.98 \pm 0.09$ & $25.31 \pm 0.37$ & $25.06 \pm 0.11$ & - \\
\hline (C18:2) & $52.12 \pm 1.86$ & $35.27 \pm 0.37$ & $48.36 \pm 0.14$ & $56.97 \pm 0.20$ & $55.73 \pm 0.62$ & - & $58.15 \pm 0.25$ & $55.47 \pm 0.15$ & $55.61 \pm 0.33$ & - \\
\hline (C18:3) & $0.56 \pm 0.12$ & $3.93 \pm 0.07$ & 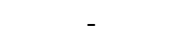 & $0.56 \pm 0.06$ & $0.20 \pm 0.01$ & - & - & $0.34 \pm 0.06$ & $0.21 \pm 0.02$ & - \\
\hline (C20:0) & - & - & - & $0.21 \pm 0.03$ & $0.25 \pm 0.04$ & - & - & $0.21 \pm 0.1$ & - & - \\
\hline (C20:2) & $0.65 \pm 0.26$ & - & - & $0.75 \pm 0.01$ & $2.68 \pm 0.29$ & - & - & $2.80 \pm 0.13$ & $2 . .95 \pm 0.03$ & - \\
\hline (C22:2) & - & - & - & $0.71 \pm 0.07$ & - & - & - & - & - & - \\
\hline
\end{tabular}

Table 2. Fatty acid percentages of black cumin oil capsules

\begin{tabular}{|c|c|c|c|c|c|c|c|c|c|c|}
\hline Fatty Acid & NOC 1 & NOC 2 & NOC 3 & NOC 4 & NOC 5 & NOC 6 & NOC 7 & NOC 8 & NOC 9 & NOC 10 \\
\hline (C14:0) & $0.13 \pm 0.04$ & - & - & $0.08 \pm 0.02$ & $0.13 \pm 0.01$ & $0.16 \pm 0.01$ & $0.07 \pm 0.01$ & - & $0.12 \pm 0.01$ & $0.13 \pm 0.01$ \\
\hline (C16:0) & $11.34 \pm 0.06$ & $8.89 \pm 0.11$ & $12.04 \pm 0.05$ & $7.90 \pm 0.09$ & $11.28 \pm 0.03$ & $12.71 \pm 0.03$ & $10.66 \pm 0.25$ & $8.34 \pm 0.07$ & $12.34 \pm 0.47$ & $11.99 \pm 0.13$ \\
\hline (C16:1) & - & - & - & - & - & $0.15 \pm 0.01$ & $0.13 \pm 0.09$ & - & $0.17 \pm 0.02$ & - \\
\hline (C18:0) & $3.90 \pm 0.07$ & $3.14 \pm 0.01$ & $3.53 \pm 0.04$ & $3.98 \pm 0.08$ & $3.89 \pm 0.06$ & $3.66 \pm 0.23$ & $5.42 \pm 0.05$ & $3.90 \pm 0.29$ & $3.87 \pm 0.11$ & $3.93 \pm 0.03$ \\
\hline (C18:1) & $27.38 \pm 0.11$ & $46.71 \pm 0.07$ & $24.93 \pm 0.06$ & $34.35 \pm 0.39$ & $27.34 \pm 0.04$ & $26.39 \pm 0.47$ & $35.08 \pm 0.18$ & $31.13 \pm 0.17$ & $26.34 \pm 0.18$ & $27.19 \pm 0.28$ \\
\hline (C18:2) & $50.61 \pm 0.17$ & $36.67 \pm 0.1$ & $56.45 \pm 0.40$ & $52.84 \pm 0.06$ & $50.31 \pm 0.03$ & $53.84 \pm 1.28$ & $45.15 \pm 0.20$ & $56.61 \pm 0.46$ & $54.38 \pm 0.44$ & $53.63 \pm 0.56$ \\
\hline (C18:3) & $0.59 \pm 0.05$ & $2.94 \pm 0.04$ & - & - & $0.62 \pm 0.07$ & - & $1.68 \pm 0.07$ & - & - & - \\
\hline (C20:0) & - & - & - & - & - & - & $0.52 \pm 0.09$ & - & - & - \\
\hline (C20:1) & $1.14 \pm 0.04$ & - & - & - & $1.23 \pm 0.04$ & - & - & - & - & - \\
\hline (C20:2) & $2.73 \pm 0.01$ & $1.62 \pm 0.03$ & $3.05 \pm 0.09$ & $0.85 \pm 0.05$ & $2.69 \pm 011$ & $2.76 \pm 0.11$ & $1.25 \pm 0.04$ & - & $2.74 \pm 0.06$ & $3.10 \pm 0.14$ \\
\hline (C22:1) & $2.15 \pm 0.05$ & - & - & - & & - & - & - & - & - \\
\hline
\end{tabular}


Table 3. Expected ranges of fatty acid percentages in standardized black cumin seed oils

\begin{tabular}{ll} 
Fatty Acid Profile & Percentage \\
\hline C14:0 & Up to $0.2 \%$ \\
C16:0 & $7-13 \%$ \\
C16:1 & Up to $0.2 \%$ \\
C18:0 & $2-4 \%$ \\
C18:1 & $20-30 \%$ \\
C18:2 & $42-60 \%$ \\
C18:3 & Up to $1 \%$ \\
C20:0 $20: 1$ & Up to $0.5 \%$ \\
C20:2 & Up to $1.2 \%$ \\
C22:1 & Up to $3 \%$ \\
C22:2 & $2-3 \%$ \\
\hline
\end{tabular}

In conclusion, it may be stated that the fatty acid profile of a standardized seed oil is expected to be within the ranges given in Table 3 according to our results and literature survey mentioned above. This is the first study in the literature that has compared the fatty acid profiles of different branded black cumin oils and oil capsules. In our previous study [60], we investigated the thymoquinone contents of these products and when we compare these two study results, it is clear that the fatty acid profiles are not related with the amount of thymoquinone. The fatty acid profiles of NO6 and NO10 couldn't be determined although they revealed different thymoquinone percentages calculated previously. In spite of the fact that these two samples were extracted and analysed at the same time as the other samples, it may be stated that these two products are in fact counterfeit products. Consequently, this study may be a global reference for further studies in the related fields for more contributions to science.

\section{Conflict of Interest}

The authors declare no conflicts of interest.

\section{Supporting Information}

Supporting information accompanies this paper on http://www.acgpubs.org/journal/journal-ofchemical-metrology

\section{ORCID}

Selin Işık: 0000-0001-7601-3746

Sinem Aslan Erdem: 0000-0003-1504-1916

Murat Kartal: 0000-0003-3538-2769

\section{References}

[1] S. Padhye, S. Banerjee, A. Ahmad, R. Mohammad and F. H. Sarkar (2008). From here to eternity-the secret of Pharaohs: Therapeutic potential of black cumin seeds and beyond, Cancer Ther. 6, 495-510.

[2] A. Kooshki, R. Forouzan, M. H. Rakhshani and M. Mohammadi (2016). Effect of topical application of Nigella sativa oil and oral acetaminophen on pain in elderly with knee osteoarthritis: A crossover clinical trial, Electron. physician. 8, 31933197.

[3] S. Basay, N. Surmeli, G. Okcu and I. Demir (2006). Changes in germination percentages, protein and lipid contents of primed pepper seeds during storage, Acta Agric. Scand. Sect. B-Soil Plant Sci. 56, 138-142. 
[4] H. S. El-Abhar, D. M. Abdallah and S. Saleh (2003). Gastroprotective activity of Nigella sativa oil and its constituent, thymoquinone, against gastric mucosal injury induced by ischaemia/reperfusion in rats, J. Ethnopharmacol., 84, 251258.

[5] P. J. Houghton, R. Zarka, B. de las Heras and J. Hoult (1995). Fixed oil of Nigella sativa and derived thymoquinone inhibit eicosanoid generation in leukocytes and membrane lipid peroxidation, Planta Med. 61, 33-36.

[6] A. Rohman, D. W. Sudjadi, E. Lukitaningsih and A.S. Rosman (2015). Use of fourier transform infrared spectroscopy in combination with partialleast square for authentication of black seed oil, Init. J. Food Prop. 18(4), 775-784.

[7] F. N. Arslan, G. Akin, Ş. N. Karuk Elmas, İ. Yılmaz, H. G. Janssen and A. Kenar (2019). Rapid detection of authenticity and adulteration of cold pressed black cumin T seed oil: A comparative study of ATR-FTIR spectroscopy and synchronous fluorescence with multivariate data analysis, Food Control 98, 323-332.

[8] K. Suri, B., Singh, A., Kaur, M. P. Yadav and N. Singh (2019). Impact of infrared and dry air roasting on the oxidative stability, fatty acid composition, Maillard reaction products and other chemical properties of black cumin (Nigella sativa L.) seed oil, Food Chem. 295, 537-547.

[9] G. Gurdeniz and B. Ozen (2009). Detection of adulteration of extra-virgin olive oil by chemometric analysis of midinfrared spectral data, Food Chem. 116(2), 519-525.

[10] G. M. Mabrouk, S. S. Moselhy, S. F. Zohny, E. M. Ali, T. E. Helal, A. A. Amin and A. A. Khalifa (2002). Inhibition of methylnitrosourea (MNU) induced oxidative stress and carcinogenesis by orally administered bee honey and Nigella grains in Sprague Dawely rats, J. Exp. Clin. Cancer Res. CR 21, 341-346.

[11] C. C. Woo, S. Y. Loo, V. Gee, C. W. Yap, G. Sethi, A. P. Kumar and K. H. Tan (2011). Anticancer activity of thymoquinone in breast cancer cells: possible involvement of PPAR-gamma pathway, Biochem. Pharmacol. 82(5), 464475 .

[12] M. N. Nagi and M. A. Mansour (2000). Protective effect of thymoquinone against doxorubicin-induced cardiotoxicity in rats: a possible mechanism of protection, Pharmacol. Res. Off. J. Ital. Pharmacol. Soc. 41(3), 283-289.

[13] S. Bourgou, A. Pichette, B. Marzouk and J. Legault (2012). Antioxidant, anti- inflammatory, anticancer and antibacterial activities of extracts from Nigella sativa (black cumin) plant parts, J. Food Biochem. 36, 539-546.

[14] M. U. Bashir and H. J. Qureshi (2010). Analgesic effect of Nigella sativa seeds extract on experimentally induced pain in albino mice, J. Coll. Physicians Surg. Pak. 20, 464-467.

[15] N. Mert, Z.T. Ağaoğlu, , H. Gündüz, , A. Ertekin and S. Dede (2000). Nigella sativa (çörek otu), vitamin C, E ve selenyum, nitrosoguanidin uygulanan tavşanların tüylerindeki iz element seviyelerine etkileri, Uludağ Üniverstesi Tip Fakültesi Derg. 26, 87-90.

[16] W. H. Talib and M. M. Abukhader (2013). Combinatorial effects of thymoquinone on the anticancer activity and hepatotoxicity of the prodrug CB 1954, Sci. Pharm. 81(2), 519-530.

[17] S. Attoub, O. Sperandio, H. Raza, K. Arafat, S. Al-Salam, M. A. Al Sultan, M. Al Safi, T. Takahashi and A. Adem (2013). Thymoquinone as an anticancer agent: Evidence from inhibition of cancer cells viability and invasion in vitro and tumor growth in vivo, Fundam. Clin. Pharmacol. 27(5), 557-569.

[18] E. S. Al-Sheddi, N. N. Farshori, M. M. Al-Oqail, J. Musarrat, A. A. Al-Khedhairy and M. A. Siddiqui (2014). Cytotoxicity of Nigella sativa Seed Oil and Extract Against Human Lung Cancer Cell Line, Asian Pac. J. Cancer Prev. 15(2), 983987.

[19] L. Peng, A. Liu, Y. Shen, H. Z. Xu, S. Z. Yang, X. Z. Ying, W. Liao, H. X. Liu, Z. Q. Lin, Q. Y. Chen, S. W. Cheng and W. D. Shen (2013). Antitumor and anti-angiogenesis effects of thymoquinone on osteosarcoma through the NF- $\kappa B$ pathway, Oncol. Rep. 29(2), 571-578.

[20] E. S. M. Ammar, N. M. Gameil, N. M. Shawky and M. A. Nader (2011). Comparative evaluation of anti-inflammatory properties of thymoquinone and curcumin using an asthmatic murine model, Int. Immunopharmacol. 11(12), 2232- 2236.

[21] M. El Gazzar, R. El Mezayen, J. C. Marecki, M. R. Nicolls, A. Canastar and S. C. Dreskin (2006). Anti-inflammatory effect of thymoquinone in a mouse model of allergic lung inflammation, Int. Immunopharmacol. 6, 1135-1142.

[22] N. M. Morsi (2000). Antimicrobial effect of crude extracts of Nigella sativa on multiple antibiotics-resistant bacteria, Acta Microbiol. Pol. 49, 63-74.

[23] H. Hosseinzadeh, B. S. F. Bazzaz and M. M. Haghi (2007). Antibacterial activity of total extracts and essential oil of Nigella sativa L. seeds in mice, Pharmacologyonline 2, 429-435.

[24] H. A. Bakathir and N. A. Abbas (2011). Detection of the antibacterial effect of Nigella sativa ground seeds with water, Afr. J. Tradit. Complement. Altern. Med. AJTCAM Afr. Netw. Ethnomedicines 8(2),159-164.

[25] M. S. M. Hanafy and M. E. Hatem (1991). Studies on the antimicrobial activity of Nigella sativa seed (black cumin), $J$. Ethnopharmacol. 34, 275-278.

[26] O. Evirgen, A. Gökçe, O. H. Ozturk, E. Nacar, Y. Onlen and B. Ozer (2011). Effect of thymoquinone on oxidative stress in Escherichia coli-induced pyelonephritis in rats, Curr. Ther. Res. 72, 204-215.

[27] M. Burits and F. Bucar (2000). Antioxidant activity of Nigella sativa essential oil, Phytother Res. 14(5), 323-328.

[28] A. Meziti, H. Meziti, K. Boudiaf, B. Mustapha and H. Bouriche (2012). Polyphenolic profile and antioxidant activities of Nigella sativa seed extracts in vitro and in vivo, World Acad. Sci. 6(4), 109-117.

[29] H. Harzallah, R. Grayaa, W. Kharoubi, A. Maaloul, M. Hammami and T. Mahjoub (2012). Thymoquinone, the Nigella sativa bioactive compound, prevents circulatory oxidative stress caused by 1,2-dimethylhydrazine in erythrocyte during colon postinitiation carcinogenesis, Oxid. Med. Cell. Longev. 2012.

[30] W. M. Abdel Wahab (2013). Protective effect of thymoquinone on sodium fluoride-induced hepatotoxicity and oxidative stress in rats, J. Basic Appl. Zool. 66(5), 263-270.

[31] G. Singh, P. Marimuthu, C. S. De Heluani and C. Catalan (2005). Chemical constituents and antimicrobial and antioxidant potentials of essential oil and acetone extract of Nigella sativa seeds, J. Sci. Food Agric. 85(13), 2297-2306. 
[32] N. B. Thippeswamy and K. A. Naidu (2005). Antioxidant potency of cumin varieties-cumin, black cumin and bitter cumin-on antioxidant systems, Eur. Food Res. Technol. 6, 472-476.

[33] J. Javanbakht, R. Hobbenaghi, E. Hosseini, A. M. Bahrami, F. Khadivar, S. Fathi and M. A. M. Hassan (2013). Histopathological investigation of neuroprotective effects of Nigella sativa on motor neurons anterior horn spinal cord after sciatic nerve crush in rats, Pathol. Biol. 61, 250-253.

[34] R. Hobbenaghi, J. Javanbakht, S. Sadeghzadeh, D. Kheradmand, F. S. Abdi, M. H. Jaberi, M. R. Mohammadiyan, F. Khadivar and Y. Mollaei (2014). Neuroprotective effects of Nigella sativa extract on cell death in hippocampal neurons following experimental global cerebral ischemia-reperfusion injury in rats, J. Neurol. Sci. 337, 74-79.

[35] M. Akhtar, A. M. Maikiyo, A. K. Najmi, R. Khanam, M. Mujeeb and M. Aqil (2013). Neuroprotective effects of chloroform and petroleum ether extracts of Nigella sativa in stroke model of rats, J. Pharm. Bioall. Sci. 5(2), 119-125.

[36] I. Ullah, N. Ullah, M. I. Naseer, H. Y. Lee and M. O. Kim (2012). Neuroprotection with metformin and thymoquinone against ethanol-induced apoptotic neurodegeneration in prenatal rat cortical neurons, BMC Neurosci. 13(1), 11 (11 pages).

[37] S. H. Mousavi, Z. Tayarani-Najaran, M. Asghari and H. R. Sadeghnia (2010). Protective effect of Nigella sativa extract and thymoquinone on serum/glucose deprivation-induced PC12 cells death, Cell. Mol. Neurobiol. 30(4), 591-598.

[38] R. Sedaghat, M. Roghani and M. Khalili (2014). Neuroprotective effect of thymoquinone, the Nigella sativa bioactive compound, in 6-hydroxydopamine-induced hemi-parkinsonian rat model, Iran. J. Pharm. Res. 13(1): 227-234.

[39] A. A. Al-Majed, F. A. Al-Omar and M. N. Nagi (2006). Neuroprotective effects of thymoquinone against transient forebrain ischemia in the rat hippocampus, Eur. J. Pharmacol. 543(1-3), 40-47.

[40] M. Kanter, H. Demir, C. Karakaya and H. Ozbek (2005). Gastroprotective activity of Nigella sativa L. oil and its constituent, thymoquinone against acute alcohol-induced gastric mucosal injury in rats, World J. Gastroenterol. 11(42), $6662-6666$

[41] M. Khazaei and H. Salehi (2006). Protective effect of Falcaria vulgaris extract on ethanol induced gastric ulcer in rat, Iran. J. Pharmacol. Ther. 5(1), 43-0.

[42] S. Tsuji, S. Kawano, N. Sato and T. Kamada (1990). Mucosal blood flow stasis and hypoxemia as the pathogenesis of acute gastric mucosal injury: role of endogenous leukotrienes and prostaglandins, J. Clin. Gastroenterol. 12, 85-91.

[43] S. O. Arslan, E. Gelir, F. Armutcu, O. Coskun, A. Gurel, H. Sayan and I. L. Celik (2005). The protective effect of thymoquinone on ethanol-induced acute gastric damage in the rat, Nutr. Res. 25(7), 673-680.

[44] M. El-Dakhakhny, M. Barakat, M. A. El-Halim and S. M. Aly (2000). Effects of Nigella sativa oil on gastric secretion and ethanol induced ulcer in rats.,J. Ethnopharmacol. 72, 299-304.

[45] S. F. Zaidi, K. Yamada, M. Kadowaki, K. Usmanghani and T. Sugiyama (2009). Bactericidal activity of medicinal plants, employed for the treatment of gastrointestinal ailments, against Helicobacter pylori, J. Ethnopharmacol. 121(2), $286-291$.

[46] K. A. Abdel-Sater (2009). Gastroprotective effects of Nigella sativa oil on the formation of stress gastritis in hypothyroidal rats, Int. J. Physiol. Pathophysiol. Pharmacol. 1(2): 143-149.

[47] Rifat-Uz-Zaman, M. S. Akhtar and M. S. Khan, (2004). Gastroprotective and anti-secretary effect of Nigella sativa seed and its extracts in indomethacin-treated rats, Pak J Biol Sci. 7, 995-1000.

[48] R. Thilakarathna, G. Madhusankha and S. Navaratne (2018). Determination of composition of fatty acid profile of Ethiopian and Indian black cumin oil (Nigella sativa), J. Food Sci. Technol. 3(3), 01-03.

[49] A. Uğur, I. Süntar, S. Aslan, I. E. Orhan, M. Kartal, N. Şekeroğlu, D. Eşiyok and B. Şener (2010). Variations in fatty acid compositions of the seed oil of Eruca sativa Mill. caused by different sowing periods and nitrogen forms, Pharmacogn. Mag. 6, 305-308.

[50] R. A. Kaskoos (2011). Fatty acid composition of black cumin oil from Iraq, Res. J. Med. Plant 5, 85-89.

[51] H. Lutterodt, M. Luther, M. Slavin, J.-J. Yin, J. Parry, J.-M. Gao and L. L. Yu (2010). Fatty acid profile, thymoquinone content, oxidative stability, and antioxidant properties of cold-pressed black cumin seed oils, LWT-Food Sci. Technol. 43, $1409-1413$.

[52] V. K. Babayan, D. Koottungal and G. A. Halaby (1978). Proximate analysis, fatty acid and amino acid composition of Nigella sativa L. seeds, J. Food Sci. 43(4), 1314-1315.

[53] M. F. Ramadan, J.-Th. Mörsel (2002). Characterization of phospholipid composition of black cumin (Nigella sativa L.) seed oil, Nahr. - Food 46(4), 240-244.

[54] E. Tulukcu (2011). A comparative study on fatty acid composition of black cumin obtained from different regions of Turkey, Iran and Syria, Afr. J. Agric. Res. 6(4), 892-895.

[55] M. B. Atta (2003). Some characteristics of nigella (Nigella sativa L.) seed cultivated in Egypt and its lipid profile, Food Chem. 83, 63-68.

[56] I. Demirbolat and M. Kartal (2019). Turkish Pharmacopoeia black cumin seed oil monograph, Turk. Farmakope Derg. 4(1), 18-21.

[57] E. M. Hernandez (2016). 4 - Specialty Oils: Functional and Nutraceutical Properties, Functional Dietary Lipids, ed: T. A. B. Sanders, Woodhead Publishing, pp. 69-101.

[58] S. Lopez, B. Bermudez, Y. M. Pacheco, A. Ortega, L. M. Varela, R. Abia and F. J. G. Muriana (2010). Chapter 154 Oleic Acid: The Main Component of Olive Oil on Postprandial Metabolic Processes, Olives and Olive Oil in Health and Disease Prevention, ed: V. R. Preedy and R. R. Watson, Academic Press, pp. 1385- 1393. 
[59] R. J. Jandacek (2017). Linoleic Acid: A Nutritional Quandary, Healthcare (Basel), 5(2), 25 (8 pages).

[60] S. Isik, M. Kartal and S. A. Erdem. Quantitative analysis of thymoquinone in Nigella sativa L.(Black cumin) seeds and commercial seed oils and seed oil capsules from Turkey, J. Fac. Pharm. Ankara 41, 34-41.

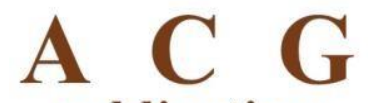

publications

(C) 2019 ACG Publications 